\title{
Medicina e saber erudito em Portugal no Renascimento*
}

LIGIA BELLINI**

Resumo: Procura-se, no artigo, traçar um quadro geral das principais influências no saber médico em Portugal, nos começos da época moderna. Såo focalizados os escritos e atividades de estudiosos que se graduaram e lecionavam em universidades, nos cursos de medicina, e atendiam a uma clientela de elite. A medicina portuguesa é abordada como parte de um contexto intelectual mais amplo, incluindo as principais disciplinas acadèmicas do periodo (filosofia, teologia, direito, medicina e literatura) e os paises europeus que recebiam e produziam obras sobre as mesmas. Entre as questôes exploradas, estão a de como essas influências intelectuais encontram-se combinadas nos tratados médicos; em que ambiente social e institucional isto ocorreu; e de que formas acontecimentos nesse contexto afetaram o conhecimento e a formaçio médicos.

Abstract: The present article is concerned with drawing a general picture of the influences on medical scholarship in early modern Portugal. We focus on the writings and activities of doctors who graduated and taught in universities, and were physicians to a powerful clientele. Portuguese scholarship is considered here as part of a broader intellectual milieu including all European countries which received and produced printed and manuscript books on the main subjects of the day (philosophy, theology, law, medicine and literature). The article attempts to provide answers to questions such as: in which ways have medical writers drawn upon the influences studied and how are they combined in their works? In which social and institutional context did this occur? How did developments in this context affect medicine and medical education?

Palavras-chave: Saber médico, Portugal. Renascimento.

Key words: Medical knowledge. Portugal. Renaissence.

O tratado português quinhentista de deontologia médica intitulado Dialogo da perfeyçam e partes que sam necessarias ao bom medico (1562), de Jeronimo de Miranda, consiste numa conversação entre um médico e um velho professor de retórica e grego. Na parte

* O presente artigo foi escrito com base em pesquisa patrocinada pelo Conselho Nacional de Desenvolvimento Científico e Tecrológico, CNPq.

** Professora Adjunto do Departamento de História, Universidade Federal da Bahia. E. mail: ligiabelliniøuol.com.br 
central do diálogo, os dois personagens concordam que, em primeiro lugar, um doutor competente deveria saber bem o latim, o grego e o árabe, para poder ler, no original, os textos das autoridades na área. Entre estes, são citados trabalhos de Celso, Hipócrates, Galeno, Avicena, Aristóteles, Platão, Rhazes e Averroes. Concordam também que um bom médico deveria conhecer filosofia natural, astrologia, aritmética, música, e principalmente ter sido ensinado por doutores letrados. Além disso, deveria praticar anatomia, para visualizar, no corpo, noções mencionadas nos textos, e ser experiente, paciente, judicioso, bem educado, honesto, entre outras qualidades (Miranda, 1562, fol. 10v-16r).

Nenhum dos autores médicos do período parece ter cumprido inteiramente uma gama tão vasta de requisitos. Esses autores também não constituem um conjunto homogêneo no que diz respeito a interesses e abordagens. Entretanto, o modelo configurado no diálogo de Jerônimo de Miranda nos permite traçar um esboço geral dos atributos e ideais do grupo de médicos cujo trabalho e ambiente são focalizados neste artigo.

O saber médico em Portugal, nos começos da época moderna, é tratado aqui como parte de um contexto intelectual amplo, incluindo todos os países europeus que recebiam e produziam livros impressos e manuscritos sobre as principais disciplinas acadêmicas do período (filosofia, teologia, direito, medicina e literatura). Tal contexto é caracterizado por Ian Maclean como situando-se "após o estabelecimento da imprensa como um meio de disseminação de textos e antes do desenvolvimento de fortes tradições vernáculas e intelectuais nacionais" (Maclean, 1987, p. 2). Como é bem conhecido, nesse universo uma herança cultural da Europa ocidental medieval, cujo escopo havia sido consideravelmente ampliado e de certo modo modificado pela redescoberta de textos gregos e latinos, coexistia com um crescente, mas ainda não dominante, conjunto de novos conhecimentos, gerados pelo desenvolvimento de abordagens ligadas à observação, experimentaçāo e matemática em diversas áreas do saber. Mudanças nesse quadro, ligadas ao aumento da importância das novas abordagens, ocorreram de um modo geral durante o século XVII. Através do estudo dos autores médicos e sua relação com seu ambiente cultural, procura-se compreender de forma mais matizada as correntes existentes no domínio acadêmico em Portugal no século XVI.

Entre as características que os doutores analisados neste artigo tinham em comum, destacam-se a qualificação formal e o status profissional e social. Sem exceção, eles graduaram-se em universidades e combinavam pelo menos duas das mais presti- 
giosas ocupaçōes médicas da época - as de professor universitário, autor e médico de uma clientela de elite. Por essa razão, dá-se ênfase à medicina lecionada nas universidades. Além disso, foi nas universidades que ocorreu a maior parte das inovaçōes no saber e formação médicos na Europa do século XVI, apesar destas preservarem, em linhas gerais, um currículo medieval.

Consideramos que o estudo da medicina erudita ilumina as doutrinas que constituiam a infra-estrutura intelectual de crenças e procedimentos amplamente disseminados entre indivíduos de diversos setores que praticavam a cura. Em algumas passagens deste trabalho, procura-se comparar o modo como conceitos são expressos e utilizados em diferentes áreas, por exemplo, entre práticos que atuavam fora do domínio acadêmico e doutores formados na universidade. Afora isto, nāo procuramos explorar aqui temas relevantes para uma compreensão do contexto médico do século XVI, como a diversidade social dos seus praticantes, a cirurgia, a botânica e a farmacologia médicas. Pouco é dito sobre instrução clínica no hospital e nada sobre tópicos importantes como as pestes e as novas doenças da época, a exemplo da sífilis. Investigar um tão vasto espectro de tópicos iria além dos propósitos deste artigo. Procuramos apenas oferecer uma resposta a questões como: Quais eram as mais importantes influências na área médica acadêmica em Portugal no século XVI? De que formas os doutores utilizaram essas influências, e como estas encontram-se combinadas em seus trabalhos? Em que contexto social e institucional isto ocorreu? Como acontecimentos nesse contexto afetaram o conhecimento e a formação médicos? Para responder a estas questões, é importante considerar inicialmente as relações sociais e institucionais dos autores estudados.

\section{1}

As páginas preliminares do Dialogo da perfeyçam... de Miranda, obra dedicada ao rei D. Sebastião (que reinou de 1568 a 1578), contêm dois poemas elogiando o monarca, os feitos da nação portuguesa na expansão marítima, e suas guerras e domínios alémmar. O diálogo contém ainda poemas dedicados à rainha Catarina (?-1578), viúva do rei D. João III, e ao Cardeal D. Henrique (15121580 ), ambos regentes durante a menoridade de D. Sebastião (1557-1567). Na dedicatória do diálogo ao jovem monarca, Miranda descreve o seu conteúdo como "as letras, experiencia, \& honestidade, \& outras virtudes que ha de ter o bom medico, pera ter 
cuydado de auisar aos Reys \& Principes na saude, \& os curar nas doenças, \& como ha de ter diligencia grandissima e continua com os pacientes" (Miranda, 1562, fol, 4r).

Uma variedade de fontes nos dá indicaçōes sobre a estreita relação entre a medicina acadêmica e o poder central, em Portugal quinhentista. Entre estas, incluem-se as dedicatórias de livros, já que, como é sabido, em geral este gesto implicava patronagem do homenageado para o autor. Dos textos médicos estudados, Problematum libri quinq, de Antonio Luiz (Luiz, 1539a), e Ad libros tres predictionum Hippocr., de Enrique de Cuellar (Cuellar, 1543), são dedicados a D. João III (cujo reino se estendeu de 1521 a 1557), com ambos os autores fazendo referência às virtudes militares e poder colonial do monarca. In pluribus ex ijs quibus Galenus impugnatur ab Andrea Vesalio..., de Afonso Rodrigues de Guevara, é dedicado à Rainha Catarina, mas empenhado sobretudo em elogiar D. Joāo III (que já havia morrido quando a obra foi publicada) por seu papel na ampliação e melhoria das condições da universidade (Guevara, 1559).! A Opera omnia in Galeni libros, de Thomaz Rodrigues da Veiga, é dedicada a D. Sebastião, com palavras escritas antes da morte do monarca (Veiga, 1587). Outros tratados médicos são dedicados a membros da elite política. Este é o caso de Apologetica disceptatio, qua docetur per quae loca sanguis mitti debeat in viscerú inflammationibus..., de Pierre Brissot (publicado postumamente em 1525), dedicado ao Cardeal Afonso (nascido em 1509), irmão de D. Joāo III (Brissot, 1525); De Re Medica Opera, de Antonio Luiz, dedicado ao intelectual e alto administrador João de Barros (1496-1570) (Luiz, 1540a); e Commentarii De Varia Rei Medicae Lectione, de Garcia Lopes, dedicado ao governador e comandante militar João Mascarenhas (Garcia Lopes, 1564).

\footnotetext{
Havia apenas uma universidade em Portugal, no periodo que nos interessa centralmente neste trabalho. Desde sua fundasăo, no final do século XIII, ela localizou-se alternadamente nas cidades de Coimbra e Lisboa. A interferência direta do rei na universidade parece ter-se iniciado durante o reinado de D. Manuel I (1495-1521). que promulgou novos estatutos aproximadamente em 1504. Em 1537, a universidade foi transferida de Lisboa para Coimbra, onde a instituiçāo já havia funcionado anteriormente (de 1308 a 1338 ; e de 1354 a 1377). A transferência para Coimbra em 1537 foi feita por iniciativa de D. João III, apontado como especialmente comprometido com o desenvolvimento da instituiçđ̃o. João III não apenas deu à universidade meThores instalaçōes e maiores fundos, mas também selecionou pessoalmente parte do corpo docente (Tavares de Sousa, 1982, p. 166-167). Outra universidade foi fundada pela Companhia de Jesus em Evora em 1559 , mas suas atividades, que tiveram inicio alguns anos depois, tềm apenas interesse marginal neste estudo (Saraiva. 1950-62, v. 2, p. 208).
} 
Este não é um fenômeno restrito a Portugal. Mas pertencer à entourage do monarca parece ter tido uma relevância especial no contexto português, já que, neste, a maior parte das atividades estava ligada à corte e dependia do seu patrocínio. O rei podia garantir para seus protegidos uma cadeira na universidade, por estar diretamente envolvido na seleção dos professores. D. João III escolheu pessoalmente docentes como Enrique de Cuellar (c. 1483c. 1544), que lecionou Galeno na Cadeira de prima (1537-1544); Thomaz Rodrigues da Veiga (1513-1579), que lecionou textos do Corpus Hipocrático e Rhazes na Cadeira de vespera (1538-1557), e Galeno na Cadeira de prima (1557-1579); e Antonio Luiz ( +1565$)$, que ensinou Aristóteles (1547-1548) e Galeno (1547-1550) numa das chamadas cadeiras menores de medicina, na Universidade de Coimbra (Rocha Brito, 1937, p. 5-15; Silva Dias, 1988, p. 43-44).

Ser médico da família real era outra posição prestigiosa que podia ser ocupada na corte. As idéias controversas do médico francês Pierre Brissot a respeito do local, no corpo, onde a sangria deveria ser praticada (discutidas com mais detalhe adiante) adquiriram notoriedade entre os doutores portugueses quando Brissot tratou D. Manuel I de uma "pleurisia" (1518), contra a opinião do "physico-mor" do reino (Lemos, 1899, v. 1, p. 302). Para citar outros exemplos, parte do prestigio de Thomaz Rodrigues da Veiga, descendente de uma familia de médicos dos reis ibéricos, se deve ao fato de que ele próprio era médico da familia real (Friedenwald, 1967 , v. 1, p. 290-294). Este é também o caso de Garcia Lopes (datas não conhecidas). Uma passagem dos seus Commentarii de Varia Rei Medicae Lectione consiste numa discussão da doutrina hipocráticogalênica da influência de fatores climáticos e ambientais sobre o corpo humano, relacionando-os com as fases da vida humana. A motivação central de Garcia Lopes é responder a uma consulta sobre a conveniência, em termos médicos, do rei D. Sebastiāo, então com sete anos de idade, viajar de Lisboa até Santarém (Garcia Lopes, 1564 , fol. $6 \mathrm{v}$. e segs.).

Um relato da longa estada em Portugal do espanhol Afonso Rodrigues de Guevara ilustra diferentes aspectos da relação entre a medicina acadêmica e a corte, entre eles as vantagens pessoais que podiam resultar dessa relação. Guevara (datas năo conhecidas), licenciado em medicina pela Universidade de Siguenza na Espanha, havia depois estudado anatomia em Bolonha. Ele era um conhecido professor de anatomia na universidade espanhola de Valladolid, quando foi convidado por D. João III para ensinar esta disciplina em Coimbra, como parte da reforma da universidade promovida pelo monarca. Guevara teve um encontro com o rei e a 
rainha em 1550. Segundo o que relata em seu livro, ele dissecou o coração de um animal na presença do casal real, bem de acordo com o caráter espetacular que a prática da anatomia havia adquirido na época ${ }^{7}$ (Guevara, 1559, dedicatória). Guevara começou a ensinar em Coimbra em 1556, pouco antes da morte de D. João III. Sua amizade com a Rainha Catarina the valeu muitos favores. Em 1557, uma cadeira de cirurgia foi criada na universidade, para que ele a lecionasse junto com a de anatomia. Apesar de ter duas disciplinas a seu encargo, atas do conselho da universidade indicam que ele se ausentava freqüentemente, para viajar para a corte em Lisboa e para a Espanha. Entre as dissecaçỏes anatômicas mencionadas em seu livro, incluindo anatomias em corpos humanos, Guevara apenas uma vez faz referência a dissecações praticadas em Coimbra durante o tempo em que estava ensinando lá, e estas foram feitas em corpos de animais (Guevara, 1559, p. 269).

Em 1561, Guevara mudou-se para Lisboa, sendo nomeado médico da rainha e do Hospital de Todos os Santos, no qual the foi confiada a tarefa de organizar o ensino de anatomia e cirurgia. Apesar de conhecermos uma determinação obrigando-o a praticar anatomia no hospital, não há indicação, nas fontes, quanto ao cumprimento dessa ordem. Em resumo, tudo leva a crer que, apesar de ter sido um anatomista competente, potencialmente capaz de exercer uma importante influencia no que concerne à anatomia e à observação empírica, Guevara pouco fez, tanto na universidade quanto no hospital. Sua participaçăo nas atividades da corte e feitos militares parece ter sido mais intensa que sua performance como educador. Isto é sugerido pelo fato de que ele se encontrava entre os soldados e nobres aprisionados em Alcácer-Kebir (1578), onde a nata da nobreza portuguesa, incluindo o rei D. Sebastião, foi vencida e morta na tentativa frustrada de invadir o Marrocos (Lemos, 1899, v. 1, p. 221-223; Costa Santos, 1925b, p. 23 e segs.; Rocha Brito, 1937, p. 56-62).

As atividades profissionais e relações de Afonso de Guevara em Portugal ilustram a atração que a corte em Lisboa representava para os professores que tinham obrigação de morar e trabalhar em Coimbra, e a flexibilidade do poder central em permitir que doutores membros da corte descumprissem o regulamento da universidade. Este parece não ter sido o único exemplo de interferência real para proteger docentes cuja conduta fosse contra o regulamento da instituiçăo. Em pesquisa baseada em atas do conselho uni-

Sobre a dissecação anatômica como entretenimento em meados do século XVI, ver Wilson, 1987, p. 69. 
versitário, Teixeira de Carvalho observa que, para justificar ações contrárias às regras, "a autorização do conselho ou do reitor era fácil de obter e, quando faltava, o lente partia para Lisboa e voltava de lá armado com uma provisão régia que tudo resolvia a seu favor" (Teixeira de Carvalho, 1913, p. 544). De fato, se por um lado se pode afirmar que, no século XVI, a universidade foi favorecida por medidas dos reis portugueses para melhorar suas condiçōes materiais, corpo docente e curriculo, por outro lado, como sugerem a observação acima e o exemplo de Guevara, a instituiçăo era de muitas maneiras limitada pela interferência do rei na sua administraçăo.

Em paralelo a episódios indesejáveis como os mencionados acima, a história do ensino médico na Universidade de Coimbra, no Renascimento, tem protagonistas que se destacaram apenas por sua competência na educação e prática da medicina, não obstante terem se mantido afiliados centralmente ao saber herdado dos seus predecessores. Thomaz Rodrigues da Veiga é talvez o mais eminente exemplo. A grande estima de que Veiga gozava é expressa em diversas passagens dos escritos dos seus alunos. Por exemplo, o tratado de deontologia médica de Henrique Jorge Henriques (datas não conhecidas) intitulado Retrato del Perfecto Medico (1595), no qual Veiga é referido como um "admirable, y perfecto Medico, que otro hasta el dia de oy no ha auido dende [sic] los Gentiles" (Henriques, 1595, p. 117).' Thomaz Rodrigues da Veiga teve uma carreira médica exemplar em muitos sentidos. Ele pertencia a uma familia de médicos dos reis ibéricos e tinha ele próprio uma clientela de poderosos, incluindo os reis D. João III e D. Sebastião, e o regente Cardeal D. Henrique. Estudou medicina em Salamanca e começou a ensinar na Universidade de Coimbra quando tinha 25 anos. De ascendência judaica, ele tinha a seu favor o fato de que seus ancestrais haviam renegado havia muito a fé e os costumes hebraicos. Por essa razão, diferentemente de outros médicos judeus, Veiga não foi proibido de ensinar na universidade e não teve que deixar Portugal devido a perseguiçōes religiosas. Sua longa carreira como professor e médico foi complementada pela de autor. Ele escreveu um conjunto de comentários sobre obras de Galeno e um comentário sobre o texto hipocrático De victus ratione (Veiga, 1564; 1578; 1586; 1587).

Embora citações dos doutores da escola moderna como Andreas Vesalius (1514-1564), Joannes Argenterius (1513-1572) e Jean Fernel (1497-1558) ocorram nos comentários de Veiga sobre os

Sobre elogios a Veiga em escritos médicos, ver Lemos, 1899, v. 1, p. 313. 
textos de Galeno, atestando seu conhecimento sobre as novas abordagens do período, o médico português era adepto de uma atitude de grande respeito aos autores antigos, Galeno em particular. No prefácio do seu Opera omnia in Galeni libros, ele afirma que "entre os textos médicos considerados relevantes em nosso tempo, nenhum é tão abrangente ou tão útil quanto os de Galeno". * Veiga se refere aos textos gregos de Galeno, ou traduçôes latinas destes de acordo com os cânones dos studia humanitatis, com os tão criticados erros das versões árabes e latinas da Idade Média eliminados, e separados dos trabalhos espúrios.

\section{II}

O empenho de Thomaz Rodrigues da Veiga no estudo e interpretação de Galeno e Hipócrates expressa a intensidade com que o interesse humanista no conhecimento direto dos textos gregos contagiou a área médica acadêmica em Portugal no século XVI.

O humanismo influenciou, através de vários canais, diferentes setores da elite intelectual e política portuguesa (Ramalho, 1969, p. 33-41; 1972; 1984; Cerejeira, 1974-75, v. 1, p. 13-16; v. 2, p. 136; Saraiva, 1950-62, v. 2, p. 189-191; Kristeller, 1990, p. 73; Vasconcellos, 1929 , p. 50 e segs.). Resultaram desse processo a criação, por D. João III, do Colégio das Artes, concebido de acordo com o programa educacional humanista, e a importância adquirida por disciplinas como gramática, retórica, poesia, história e filosofia moral, que se tornaram os focos de interesse mais em voga entre os estudiosos portugueses. A maior parte dos textos acadêmicos do período, assim como as atividades promovidas na corte, evidenciam esse interesse. No entanto, mais relevante que os studia humanitatis, para a presente investigação, sāo atitudes que derivaram da sua influência, de respeito incondicional pela cultura antiga e seu renascimento moderno na Itália, e conseqüentemente uma abordagem mais dogmática e filológica aos textos antigos. Além disso, é particularmente importante o amplo corpus de escritos gregos e latinos sobre ciência e filosofia, posto em circulação pelos humanistas.

A ênfase no legado da antigüidade clássica nāo foi a característica mais marcante dos saberes associados à empresa marítima e colonial. Um desenvolvimento sem precedentes nas áreas de engenharia naval, instrumentos, astronomia náutica e cartografia ocorreu

- Ex libris, quos hactenus de re Medica scriptos nostra probauit aetas, nullus est, quem vniuersi, qui huic disciplinae nomina dederunt, aut crebrius, aut maiore cum vtilitate manibus versent quam Galen monumenta.' 
sob o patrocínio de príncipes como Henrique "O Navegador" (13941460 ) e o rei D. João II (que reinou de 1481 a 1495). Técnicas desenvolvidas anteriormente pelo italianos no Mediterrâneo tiveram que ser adaptadas pelos portugueses (e espanhóis) às inteiramente diversas condições de navegação na travessia do Atlântico, estimulando o desenvolvimento de uma corrente moderna, vinculada à razão metódica e à observação (Waters, 1967, p. 197 e segs.).

No saber português do período, o empirismo teve ainda outro tipo de desenvolvimento, associado à possibilidade oferecida pelas navegações, de observar fenômenos até então desconhecidos, ou compreendidos incorretamente, tanto nos textos antigos quanto no conhecimento europeu. Além da astronomia e geografia, essa tendência verifica-se em estudos das plantas medicinais e drogas do Oriente. Nesta última área, a corrente empírica tem sua expressão máxima nos Coloquios dos simples e drogas e cousas medicinais da India (1563), de Garcia de Orta, um estudo das ervas e drogas da India, no qual os resultados da observação direta são comparados criticamente com os trabalhos de autoridades na área como Galeno, Dioscorides e Plínio (Albuquerque, 1982).

Na medicina, com exceção do ramo de estudos botânicos e farmacológicos, o desenvolvimento do empirismo ocorreu apenas marginalmente. Isto se aplica em especial à anatomia. Pode-se afirmar que, devido à recepção de idéias vindas de outros países europeus, especialmente a Itália, Espanha e França, os autores médicos portugueses demonstram uma certa familiaridade com questōes ligadas à observação empírica. Entretanto, seus trabalhos se afiliam centralmente à tradição de comentário textual, dominante na vida intelectual européia do período.

Uma diversidade dè aspectos dos tratados médicos pesquisados indica a predominância, entre seus autores, de abordagens mais dogmáticas e filológicas aos textos antigos. Por exemplo, no primeiro capítulo de De Varia Rei Medicae Lectione, Garcia Lopes afirma que "a verdadeira medicina é aquela escrita por Hipócrates e Galeno".5 Por isso, uma preocupação central do seu livro, que trata de um conjunto de temas relacionados à terapêutica, é recuperar a "pureza" das doutrinas galênicas e hipocráticas, assinalando as adiçóes e interpretações incorretas dos autores árabes. Esta também é uma preocupação de Enrique de Cuellar. Em Ad libros tres predictionum Hippocr, a ênfase textual de Cuellar se expressa na citaçāo do texto de Hipócrates sobre prognóstico, e do comentário de Galeno sobre o

[...] si quae video, quae a magni Hippo. aut Gal. sententia aliena sunt, ea confodeo, incito, et, si fieri potest, extirpo, ne alumnos verae medecinae, (quae non est alia, quam quae ab Hipp. et Gal. scribitur) ita suo foetore corrumpant" (fol. 1v). 
mesmo, seguido por seus próprios comentários. $\mathrm{O}$ objetivo geral de "voltar aos gregos" é ainda indicado pelo empenho dos autores em afirmar que seus trabalhos se fundamentaram nos textos antigos originais. Um exemplo é o zelo de Antonio Luiz em deixar claro que havia baseado seu Problematum libri quinq; em autores gregos, citando "Galeno, Proclo, Plutarco, Platão, Aristóteles, Alcino, Alexandre, o divino Dionísio (Ps. Areopagita) e numerosos outros..." ."

Os autores médicos portugueses conheciam edições aprimoradas dos textos de Galeno, inclusive obras não conhecidas na Idade Média. De Placitis Hippocratis et Platonis e De Usu Partium sāo citados na maior parte dos textos analisados. O primeiro não havia sido traduzido antes do Renascimento, e o segundo existia apenas em forma abreviada, até o século XIV (Temkin, 1973, p. 100; French, 1979, p. 97).

A introdução de estudos hipocráticos em Portugal se deveu principalmente a Pierre Brissot (1478-1522), que lá viveu de 1518 a 1522. Sua ida para lá parece estar ligada, inicialmente, a planos de viajar para a Índia, para desenvolver estudos sobre botânica e drogas médicas. Antes disso, Brissot havia iniciado em Paris uma controvérsia médica sobre o tema da flebotomia, endossando concepçōes e procedimentos hipocráticos e galênicos contra os da medicina arábica. A controvérsia dizia respeito à evacuaçăo de humores redundantes por "revulsão" ou "derivação", procedimentos terapêuticos que eram praticados em diferentes regiőes do corpo, em relação ao local da doença. Brissot enunciou suas idéias particularmente com referência à "pleurisia", uma doença de que ele havia tratado em 1514, e que pode ter sido tanto o que é hoje em dia designado como pleurisia, como outra afecção pulmonar qualquer. Baseado em noçōes hipocráticas e galênicas, Brissot condenou a recomendação da medicina islâmica de sangrar lentamente (por vezes removendo apenas uma ou duas gotas de sangue) no local mais distante da parte afetada. Ele defendia a retirada de uma quantidade considerável de sangue e que, em caso de "pleurisia", näo importava se a sangria fosse realizada no lado direito ou esquerdo, já que a doença afetava uma regiäo drenada pela veia cava. Defendia também que uma distância suficiente para a flebotomia revulsiva, no sentido hipocrático, poderia ser atingida pela prática da sangria no braço do lado doente. Desta forma, era incorreto escolher, como de costume, a veia safena da perna.

"Auctores quos in hoc concinnando opere secutu sum: graeci fuere, atq; ij imprimis Galenus, Proclus, Plutarchus, Plato, Aristoteles, Alcinous, Alexander, diuus Dionysius, et alij innumeri...", fol. 3 r. 
Em 1518, Brissot tratou pessoas afetadas de "pleurisia" em Évora, inclusive D. Manuel I, pondo em prática seus próprios princípios, contra a opinião do físico-mor do reino, Dionysio. Gerou-se uma controvérsia também nos círculos médicos em Portugal, da qual aparecem ressonâncias nas fontes deste artigo (Guevara, 1559, p. 151 e segs. e 171; Garcia Lopes, 1564, passim, esp. fol. $73 \mathrm{v}$; Miranda, 1562, fol. $17 \mathrm{r}-17 \mathrm{v}$ ). Os dois principais opositores registraram suas opiniōes por escrito. Os argumentos de Brissot, particularmente com respeito ao modo de utilização da sangria no tratamento da "pleurisia", encontram-se em Apologetica disceptatio... O texto de Dionysio não chegou até nós.'

Se, de diversas maneiras, preceitos das autoridades antigas foram aceitos de forma acrítica pelos doutores portugueses, é importante ressaltar que isto nem sempre ocorreu. Mencionamos anteriormente o caso de Afonso de Guevara, sem dúvida o profissional melhor preparado para atuar de acordo com a observação e experimentação, entre os médicos portugueses. Em várias passagens de sua obra, Guevara se dispōe a discordar de Galeno, o autor antigo a quem ele presta tributo especial. O mesmo se verifica na obra de Rodrigo de Castro (1546-1627). Em seu De universa mulierum Medicina, Castro faz uso da observação anatômica e clínica para elucidar questōes a respeito das quais havia discordância entre as autoridades médicas, ou para afirmar que suas opiniões eram equivocadas, a despeito de, no livro como um todo, basearse em grande medida nas concepções dessas autoridades (Castro, 1603 , p. 27,37 e 65 ). Nos textos médicos portugueses, também encontram-se passagens que expressam a aceitaçāo de idéias dos neoterici, discordando dos autores antigos, embora isso não se verifique com muita freqüência. Por exemplo, com base nas Observationes anatomicae (1561) de Gabriele Falloppia, Garcia Lopes rejeita o aforismo hipocrático, afirmando que a causa do aborto sem razão aparente, no segundo ou terceiro mês de gravidez, era o rompimento dos vasos que ligam o embrião ao útero (cotyledons) que, por estarem cheios de muco, ficariam incapacitados de sustentar o peso do embrião. Lopes argumenta que, nesses casos, a causa do aborto era a interrupção da alimentação do embriāo, devido à obstrução dos vasos pelo muco, e não o seu rompimento (Garcia Lopes, 1564 , fol. $75 \mathrm{r}-78 \mathrm{v}$ ). A partir dos exemplos citados, pode-se

\footnotetext{
Sobre Pierre Brissot e sua controvérsia com Dionysio, ver Saunders et al., (p. 12-19; Lemos, 1899, v. 1, p. 301-304; e Ricardo Jorge, 1914-1916, passim; e 1924). O artigo de Saunders e O'Malley também trata do conceito de pleurisia. Para as opinioes de Galeno sobre as propriedades terapéuticas da flebotomia, ver Bylebyl, 1979a, p. 42-43.
} 
concluir que uma atitude de aceitação acrítica das autoridades coexistiu com tentativas de questionar seus preceitos. Isto não se verifica unicamente no contexto português. Na formulação de Maclean, tal coexistência "reflete as hesitações... inerentes aos modos de pensar do Renascimento" (Maclean, 1987, p. 4).

Como é bem conhecido, o interesse inicial dos humanistas do Renascimento no estudo das letras clássicas se estendeu às vernáculas. Essa tendência se expressa, entre os autores médicos portugueses, no uso das línguas ibéricas em alguns dos trabalhos estudados. O Dialogo da perfey̧̧am..., de Jerônimo de Miranda, e o Retrato del Perfecto Medico, de Henrique Jorge Henriques, são escritos em português e espanhol, respectivamente. A Ropicapnefina, de João de Barros, uma das fontes não médicas deste estudo, é escrita em português. Tentativas de escrever textos médicos na línguas vernáculas, ou de traduzir escritos dos autores antigos para o português e o espanhol, parecem ter gerado a consciência das dificuldades de traduzir conceitos e termos do latim e do grego para idiomas desaparelhados para expressar noçōes da biologia humana. Isto é indicado numa passagem do Dialogo da perfey̧̧am..., na qual Miranda nota a deficiência, nas línguas vernáculas, de palavras que correspondessem satisfatoriamente aos termos gregos e latinos. Essa deficiência é atribuída por Miranda à influência das línguas dos povos por ele considerados como "bárbaros", que habitavam a Península Ibérica (Godos e Muçulmanos), sobre as vernáculas da regiāo, na sua origem próximas do latim (Miranda, 1562, fol. 9r9v).

Também decorrente da influência humanista é a já mencionada ocorrência de peças literárias, nos tratados médicos. Epigramas e outras formas de poesia, dedicados a patronos das letras, outros autores e leitores, ou simplesmente descrevendo o trabalho que acompanham, são freqüentemente neles encontrados. As dedicatórias são escritas no estilo retórico característico dos humanistas, citando mitologia grega, pensadores e estadistas da Grécia e Roma antigas, e coisas similares. As relaçōes entre a medicina acadêmica e a literatura se expressam ainda no longo poema intitulado "Microcosmographia, e Descripçāo do Mundo Pequeno, que é o Homem", de André Falcão de Resende, que consiste numa ampla descrição da anatomia humana, escrita com base em tratados anatômicos," metaforicamente apresentada como uma viagem através do corpo. 
Os esforços no sentido de "humanizar" a medicina incluem a tentativa de adaptação de textos latinos e islâmicos do final do período medieval ao gosto literário, abordagem filológica, e necessidades científicas do século XVI (Siraisi, 1985). Uma indicação dessa tendência na medicina portuguesa é a referência de Miranda ao domínio da língua árabe como um aspecto importante na formação de um doutor, o que o tornaria capaz de ler as autoridades árabes no original. Influências humanistas incluem ainda o empenho em aprimorar a cirurgia, tornando acessível aos seus praticantes as genuínas concepçōes galênicas e hipocráticas (Nutton, 1985). $\mathrm{O}$ cirurgião português Antonio da Cruz (†1626), que teve uma formação de acordo com esses princípios, empenhou-se em ampliar o acesso à cirurgia mais erudita. Essa é a justificativa que Cruz apresenta para ter escrito sua Recopilação de Çurgia em português (Cruz, 1630; Costa Santos, 1925a, p. 7).

As influências humanistas constituem apenas um aspecto das relaçōes entre a medicina e o restante da vida intelectual no Renascimento. A medicina figura entre as mais importantes disciplinas do currículo universitário em Portugal, junto com direito (canônico e civil) e teologia. No que concerne a este particular, o currículo português é similar ao currículo das universidades do norte da Europa e difere das italianas, nas quais não havia faculdade de teologia. Como nas universidades européias em geral, a medicina em Portugal era estreitamente ligada às artes. $\mathrm{O}$ regulamento de 1559 sugere que a universidade portuguesa estava mais próxima do modelo nórdico, no qual a formação completa em artes constituía pré-requisito para o ingresso em medicina. Na Itália, artes e medicina eram cursadas paralelamente. Mas tudo indica que, na prática, ambos os esquemas eram aceitos na Universidade de Coimbra (Estatutos..., 1963).'

O currículo de artes em Coimbra concentrava-se na lógica e filosofia natural aristotélicas, em conjunto com uma ênfase menor em filosofia moral e metafísica, astronomia, aritmética, geometria e perspectiva. Requeria o domínio inicial do latim pelo estudante, e dava a este treinamento intensivo em debate formal (Estatutos..., 1963, p. 314-321). Estes são, em linhas gerais, as disciplinas e exercícios predominantes na Europa como um todo, do século XIV ao XVI (Siraisi, 1990, p. 66; Schmitt, 1985, p. 4).

tificio maravilloso em forma dé suéno o ficcion (1542), e Bernardino de Monserrate, Libro de la Anathomia del höbre (Valladolid, 1550). Ver Pina, 1942; e 1946, p. 61 esegs.

Sobre a vigéncia tanto do modelo nórdico como do italiano, no que diz respeíto à relaçāo entre artes e medicina na universidade portuguesa, ver Silva Dias, 1969, v. 1, cap. 5. Sobre outras universidades européias, ver Schmitt, 1985, nota 1, p. 271. 
A principal conseqüência da ligação entre medicina e o currículo de artes era o tipo de treinamento intelectual dos doutores formados na universidade. Tendo em vista a grade curricular brevemente descrita acima, não é surpreendente observar a orientação em grande medida filosófica dos autores médicos. Mas isto não é apenas resultado de uma educação em artes. A "conexão filosofia-medicina", como aponta Schmitt, tem raízes históricas muito antigas. Ela ocorre em diferentes versōes em todas as autoridades médicas, dos autores do Corpus Hipocrático, Galeno e Aristóteles até Avicena e Averroes (Schmitt, 1985, p. 2-3).

A inclinação filosófica do século XVI emergiu, em grande medida, da contínua discussão de temas a respeito dos quais havia discordância entre Aristóteles e Galeno. A bem conhecida questão de qual era o órgão dominante no corpo, se o coração ou o cérebro, e em que sentido, é um desses temas. Ela ocorre freqüentemente nos tratados médicos portugueses quinhentistas. ${ }^{\text {. }}$

Os doutores do Renascimento foram influenciados não apenas por Aristóteles, mas também pela filosofia platônica. Galeno, cujas doutrinas eram ainda predominantes na época, fundamentou-se em parte nas idéias de Platão. Como nota Phillip De Lacy, Galeno encontra-se entre os Platonistas que consideravam que havia amplas áreas de concordância entre Platāo e Aristóteles, e mesmo os Estóicos (Lacy, 1972, esp. p. 29). Observa-se, entre os doutores portugueses do Renascimento, essa tendência à conciliação entre Platão e Aristóteles.

A corrente platônica foi introduzida no domínio médico em Portugal através do humanismo, como ocorreu com o contexto intelectual mais amplo. Esse fenômeno é particularmente evidẹte na primeira metade do século XVI, e não influenciou igualmente todos os médicos portugueses.

Influências do pensamento platônico são especialmente proeminentes nos trabalhos de Antonio Luiz, que foram escritos até 1540 e nos quais o autor combina, de forma mais acentuada, medicina com outros elementos de sua formação humanista. $\mathrm{O}$ conhecimento, por Luiz, das línguas grega, latina e hebraica, e, por outro lado, o conteúdo de um panegírico por ele dedicado ao rei D. João III (Luiz, 1539b), atestam seus interesses filológicos e literários." Percebe-se também, em seus trabalhos, uma forte orientação filo-

* Imagens utilizadas pelos autores médicos para expressar suas opiniōes sobre essa questão săo examinadas em Bellini, 1992, cap. 5.

"I Informaçōes sobre a biografia de Antonio Luiz encontram-se em Pina, 1957, passim; e Silva Dias, 1969 , v. 1, p. 228-239. 
sófica. Temas médicos são examinados em paralelo a tópicos de filosofia natural, ética, lógica, astronomia e outros. A noção da existência de causas ocultas em medicina ocorre em seus escritos." O amplo espectro de interesses intelectuais de Antonio Luiz é referido na Panagyrica oratio, assim como no processo instaurado pelo Santo Ofício da Inquisiçāo (1539), para investigar sua ascendência judaica e idéias contrárias à ortodoxia (Silva Dias, 1969, v. 1, p. 229-230). Numa passagem de De Re Medica Opera ele afirma, com base em Galeno, que a medicina é uma arte liberal associada à prática, e não uma scientia. ${ }^{17}$ Entretanto, há várias razōes para crermos que a prática médica referida em seus livros foi retirada das obras por ele comentadas, ao invés de tratar-se de estudos de caso, relatando seu próprio trabalho no tratamento de doentes.

$\mathrm{O}$ interesse de Antonio Luiz concentrava-se no saber médico expresso em textos, e não na prática da medicina. Mas doutores que, diferentemente de Luiz, combinavam as atividades de autor e professor da universidade com a cura de pacientes eram, como ele, educados de acordo com o princípio de que disciplinas como lógica, filosofia natural e astrologia constituíam complementos indispensáveis na formação médica. Esse princípio estava em vigência desde o século XIII, nas universidades italianas. É encontrado, por exemplo, no Conciliator de Pietro d'Abano (1257-c.1315), amplamente conhecido pelos estudiosos europeus, e pelos portugueses em particular, até o final do século XVI (Schmitt, 1985, p. 3-4 e nota 18; Luiz, 1540a, fol. 109r-115r).

Que disciplinas como a filosofia natural e a astrologia eram consideradas acessórias à medicina, na Universidade de Coimbra, nos é sugerido pela menção a essa idéia nos trabalhos de deontologia médica mencionados, da autoria de Miranda e Henriques. Entretanto, se a filosofia natural dava aos futuros doutores uma base predominantemente teórica nas ciências físicas em geral, a utilidade da astrologia parece estar mais associada à prática médica. ${ }^{14}$ Os dois personagens do Retrato del Perfecto Medico de Henriques - um teólogo e um médico, o último representando o próprio autor - concordam que influências dos corpos celestes sobre o homem deveriam ser consideradas nos prognósticos e prescrição de medidas terapêuticas

12 Entre outras passagens dos livvros de Luiz, essa noçio se expressa num trecho do epigrama que acompanha seu Problematum libri quing: "Sed tamen abstrusas rerum cognoscere causas/Dum studeo..." (Luiz, 1539a, fol. 2v). Ver ainda Luiz, 1540b, passim.

"quam medicinam nuncupamus, est una artium factiuarum, e non scietia,.." (Luiz, 1540a, fol. 91r).

14 É importante notar, entretanto, que isto nem sempre ocorria. Ver Bellini, 1992, cap. 4. 
como a sangria e purgação. Uma série de autoridades, incluindo Ptolomeu, Aristóteles, Hipócrates e Rhazes, é citada em apoio a esta opiniăo. A passagem do Retrato del Perfecto Medico sobre a relevância da astrologia para a medicina sugere a importância dos autores árabes na divulgação dessa idéia, uma importância que provavelmente se devia ao papel desses autores como referência entre os que praticavam a cura (Henriques, 1595, p. 212-215).

Outras fontes indicam que praticantes da medicina fora da área acadêmica também consideravam as determinaçōes astrológicas como relevantes no exercício da sua profissão. Uma dessas fontes é o amplamente conhecido almanaque Reportorio dos Tempos, de Valentim Fernandes, publicado pelo menos nove vezes de 1518 a $1573 .{ }^{15} \mathrm{O}$ Reportorio parece ter sido prioritariamente dirigido a navegadores, mas seu conteúdo indica que foi composto tendo em vista também um público mais amplo. O Reportorio português é uma versão da edição espanhola de Andre de Li, que foi traduzida e modificada por Fernandes, de acordo com as necessidades e interesses lusitanos no que diz respeito às viagens marítimas. $\mathrm{O}$ almanaque contém calendários, descriçōes de técnicas de navegação, tabelas astronômicas, indicaçōes sobre as épocas apropriadas para a agricultura, muitas informaçōes sobre astrologia, e ainda uma seção sobre medicina astrológica."

Por outro lado, uma passagem do Dialogo da perfeyçam... de Miranda sugere que a relevância da astrologia era objeto de debate entre certos doutores da época (Miranda, 1562, fol. 10v-11r). Isto também é indicado pela ausência desse tema em parte dos tratados médicos estudados.

A complexidade de influências brevemente delineada acima nos leva a concluir que, como observam Andrew Wear, Roger French e Iain Lonie, "os autores médicos do século XVI acreditavam que estavam rompendo com seu passado árabe e medieval; que estavam criando uma reforma na medicina, cuja característica central era a purificação e assimilação do saber grego. Mas o espírito de uma reforma é uma coisa mais radical que sua prática, e ...os mais evidentes sinais de mudança se expressam nas posiçōes retóricas e ideológicas adotadas pelos médicos (Wear et al., 1985, p. xi).

15 António Joaquim Anselmo indica doze ediçōes (números 113, 229, 231, 238, 408, 558 , $566,578,628,647,666$ e 679) de 1518 a 1593 (Anselmo, 1926). Alberto Navarro faz referência a nove ediç̧̋es, de 1518 a 1573 ; ele também menciona a opiniâo de J. Bensaude, de que existiram onze ediçôes do Reportorio..., no século XVI (Navarro, 1961. p. 23-28).

is

Para uma análise dos conteúdos médicos do Reportorio dos Tempos, ver Bellíni, 1992.

p. 133-138. 
Diferentes aspectos das fontes deste estudo constituem evidência da permanência de influências medievais na medicina em Portugal, junto com inovações introduzidas com o Renascimento. As concepções médicas de Aristóteles continuavam a ser aceitas. Apesar de os doutores se identificarem primordialmente com a tradição galênico-hipocrática, noções que se encontram nos tratados estudados indicam que a autoridade de Aristóteles ainda era uma forte influência (Bellini, 1992, cap. 5). Ao menos ainda era objeto da atençāo dos estudiosos, nos debates da época. O mesmo ocorre com relação aos escritores médicos da tradição islâmica, em especial Avicena, seu mais importante representante no século XVI. O estudo de partes do Canon de Avicena e do ad Almansorem de Rhazes continuava a fazer parte do currículo da universidade portuguesa, assim como dos currículos universitários em outros lugares da Europa. Na formulação de Garcia Lopes, Avicena era "cultivado e reverenciado". O contexto em que isso é dito - uma discussão sobre se o clister deveria sempre preceder a sangria, ou apenas em certos casos - sugere uma vez mais que as autoridades árabes eram principalmente relevantes para a medicina prática (Garcia Lopes, 1564, fol. 41r-44r, citação extraída do fol. 42r).

As transformações no conhecimento médico acadêmico em Portugal no Renascimento são difficeis de determinar. Evidências de que ocorreram mudanças emergem de uma comparação entre os escritos datados da primeira metade do século XVI e aqueles produzidos de meados desse século em diante. Uma primeira obra que julgamos pertinente analisar é a Ropicapnefma, de João de Barros que, apesar de ser um texto literário, é uma interessante fonte para uma investigação sobre o saber médico em Portugal nas primeiras décadas do século XVI." A Ropicapnefma é uma alegoria sobre filosofia moral, representando a existência humana na forma de transações comerciais. Seus personagens "Vontade" e "Entendimento", tendo abandonado a "Razão" (isto é, a razão humana iluminada pela revelação cristã) em nome de uma associação com o "Tempo", haviam se tornado mercadores de vícios. No final da vida eles reencontram a "Razão", que procura encaminhá-los de volta à fé cristã e à salvação. Nesse texto, cujo conteúdo é descrito aqui de maneira muito resumida, Barros faz, em certas passagens, referência à figura do médico e à prática da medicina.

It Segundo Barros, "Ropicapnefma" é uma expressão derivada do grego, significando "mercadoria espiritual" (Barros, 1955, p. 6). Uma análise da Ropicapnefma, do ponto de vista do saber médico do período, encontra-se em David-Peyre, 1966. 
As noçōes médicas mencionadas na Ropicapnefma são concepçôes anatômicas e fisiológicas simplificadas, derivadas das idéias de Galeno, a exemplo da divisão da atividade mental em processos distintos (senso comum, imaginação, fantasia, potência estimativa e memória) localizados em regiōes específicas no cérebro (Barros, 1983, v. II, esp. p. 29-34, exemplo extraído da p. 34). A divisăo das potências da mente em cinco diferentes tipos parece ter-se fundamentado no comentário de Avicena sobre o tratado De anima, de Aristóteles (Siraisi, 1990, p. 82). Uma divisāo da atividade mental segundo modelo semelhante, mas usando um esquema ternário (potências imaginativa, estimativa e mnemônica) encontra-se no poema "Microcosmographia", de André Falcāo de Resende (Resende, 1865, Canto II, 25-26, p. 27). O poema de Resende, como já apontamos, foi escrito com base em tratados anatômicos da primeira metade do século XVI. A concepção medieval da existência de diferentes potências mentais, localizados em partes distintas do cérebro, não ocorre nos demais textos estudados, a maioria dos quais foi publicada, e presumivelmente escrita, na segunda metade do século XVI.

Os tratados médicos de Antonio Luiz foram escritos aproximadamente uma década após a Ropicapnefina. Neles, diferentemente do que se verifica quanto aos textos escritos mais tarde, menções à observação empírica estão inteiramente ausentes. Os trabalhos de Luiz podem ser considerados como exemplos de abordagens características dos inícios do século XVI, também no que diz respeito ao objetivo humanista de exclusão de adições espúrias da obra das autoridades antigas. Luiz parece ter aceitado como da autoria de Galeno o tratado intitulado An Animal Sit Id, Quod in Utero Est, erroneamente atribuído a este autor (Luiz, 1540a, fol. $81 v) .{ }^{16} \mathrm{O}$ tratado é apontado como não tendo sido escrito por Galeno em De universa mulierum Medicina, de Rodrigo de Castro, publicado no início do século XVII (Castro, 1603, lista dos autores citados na obra).

Por fim, uma análise dos modos pelos quais os doutores fundamentavam suas pesquisas e argumentaçōes no pensamento analógico nos dá indicações sobre a questão da mudança no saber médico em Portugal. Em seus estudos sobre a trajetória do pensamento grego antigo, Geoffrey Lloyd propõe uma relação entre o desenvolvimento do método científico na Grécia e a emergência de

Para a caracterizaçâo de An animal sit id... como um texto falsamente atribuído a Galeno, ver Galeni liber..., 1821-33, v. 19, p. 158-81. 
um uso mais cauteloso do argumento analógico. Este autor sugere que a clarificação de certas relações lógicas (em particular as de similaridade e identidade, e os diferentes modos de oposição) ocorreu simultaneamente ao crescimento de uma "exigência de demonstrabilidade" no pensamento grego, dos primórdios até Aristóteles (Lloyd, 1966, esp. Part Three: Conclusion). ${ }^{10}$ A proposiçāo de Lloyd ilumina o problema do desenvolvimento de abordagens mais ligadas à observação no saber renascentista. Uma conexão similar à proposta por Lloyd é postulada por Michel Foucault, no que tange aos modos de pensar dos começos do período moderno. Foucault aponta a emergência, no século XVII, de uma atitude mais crítica diante da linguagem, que foi, a partir daí, tida como representando coisas e fenômenos, ao invés de ser considerada como um signo natural dos mesmos. Um aspecto fundamental do desenvolvimento do pensamento científico é o reconhecimento de que o signo lingüístico é arbitrário, não envolvido de forma essencial com a coisa significada, mas ligado a convenções de uma linguagem. Este último modo de ver a relação entre signo e objeto significado substituiu a tradição de comentário e a preeminência da idéia da semelhança, que orientou o olhar em relação ao mundo predominante no século XVI, e que tem como pressuposto a existência de uma unidade substancial entre palavras e coisas (Foucault, 1989, p. 78 e segs.). ${ }^{20}$ À luz dessas idéias, diferenças entre os autores médicos portugueses podem ser determinadas focalizando-se os diferentes usos da analogia em seus trabalhos, assim como a amplitude em que esse mecanismo do pensamento ocorre. ${ }^{21} \mathrm{O}$ exemplo mais ilustrativo é a diferença entre um número substantivo de representaçōes do corpo humano baseadas em analogia nos trabalhos de Antonio Luiz, e um uso mais cauteloso do raciocínio analógico por alguns dos outros autores, particularmente Afonso de Guevara. Essa diferença expressa o desenvolvimento de um certo cuidado com a observação empírica na medicina, à medida que o século XVI avança, e antes do declínio do domínio acadêmico como um todo, no final desse século.

Também săo relevantes, no que diz respeito ao uso da analogia na ciência, Arber, 1947: e Hesse, 1966.

20 Para a idéia de que a relaçâo entre linguagem e realidade é tema chave na diferenciaçăo entre processos de pensamento de natureza oculta e abordagens cientificas, ver Vickers, 1984.

a Esta queståo é explorada com maior profundidade em Bellini, 1992, cap, 5. 


\section{III}

Tudo indica que, em geral, nas universidades renascentistas, o currículo de medicina não expressa de forma adequada o ambiente intelectual do domínio médico, se considerado em separado de outros aspectos desse domínio. Apesar de, por toda a Europa, os currículos serem bastante uniformes, a atmosfera acadêmica e cultural das diversas faculdades podia variar amplamente. Em certos casos, como comenta Nancy Siraisi, instituiçōes nas quais um currículo essencialmente medieval continuava a ser ministrado eram simultaneamente centros de inovação em anatomia, fisiologia e educação médica (Siraisi, 1990, p. 192). Em Portugal, entretanto, talvez mais do que em outras faculdades médicas européias, existiram possibilidades de mudança curricular no processo de remodelação e transferência da universidade de Lisboa para Coimbra, iniciado em 1537. Desta forma, a preservação, em Coimbra, de um currículo basicamente medieval pode ser considerada como refletindo uma ligação do saber e ensino da medicina em Portugal com abordagens herdadas do período medieval tardio, da mesma forma que a introdução de inovações expressa mudanças características do Renascimento.

O currículo médico em Portugal no século XVI é descrito nos regulamentos da universidade de 1504 (que foi, em linhas gerais, mantido quando a instituição foi transferida para Coimbra) e 1559 , além de decretos reais e atas do conselho universitário. A Universidade de Coimbra teve outro regulamento em 1544-45, promulgado por D. João III, mas este foi perdido.

Um breve exame dos livros-textos, importância relativa, e ordem de criação das cadeiras em Coimbra ilumina a questāo da continuidade e mudança no ensino médico em Portugal. A Cadeira de prima (1537), na qual eram ensinados textos de Galeno (Tegne; De locis affectis; De morbo et symptomate; De differentiis febrium; De simplicibus), foi a primeira a ser criada e a mais importante. A segunda cadeira na hierarquia, e segunda a ser estabelecida, foi a Cadeira de vespera (1538), dedicada ao ensino dos textos hipocráti$\cos$ (Aforismos, Sobre o regime, Epidemias e Prognóstico) e o nono livro do Almansor, de Rhazes. A seguinte Cadeira de terça (1540) baseava-se no Canon de Avicena. Textos de Galeno sobre terapêtica eram ensinados em dois outros cursos, chamados "cadeiras menores" (1546). Um deles incluía ainda o ensino de Aristóteles (Lemos, 1899, p. 170-179; Rocha Brito, 1937, esp. p. 21-22). Em 1556, foi criada uma cadeira de anatomia (os estudos anatômicos em Coimbra são discutidos adiante). Liçōes de cirurgia eram ministradas junto 
com anatomia, a partir de 1557. Esse currículo foi, em linhas gerais, mantido no regulamento da universidade de 1559 (Estatutos..., 1963, p. 295-302).

A ênfase em obras de Galeno e interpretaçôes arabizadas do pensamento galênico, característica central do conjunto de disciplinas médicas na Universidade de Coimbra, está em conformidade com os currículos médicos dos finais do período medieval e início do moderno por toda a Europa. Essa orientaçăo reflete o crescimento do ramo médico dedicado a especificidades das enfermidades e seu tratamento, nos centros de ensino europeus, e na universidade portuguesa em particular, especialmente no século XV (Siraisi, 1990, p. 152).

Como observamos anteriormente, o desenvolvimento de estudos anatômicos em Portugal mostrou-se infrutífero devido a um conjunto de circunstâncias. Em paralelo aos fatores já mencionados neste artigo, é provável que a pouca ênfase na observação empírica, no curso de medicina como um todo, tenha contribuído para o limitado desenvolvimento da anatomia. Entretanto, por outro lado, a criação da cadeira de anatomia, entre 1550 e 1556 , expressa ao menos uma tentativa de introduzir inovaçōes renascentistas no ensino médico. Para ministrar a cadeira de anatomia, foi escolhido um experiente professor, treinado em Bolonha, o que sugere um desejo de reformar o ensino médico de acordo com os modelos mais atuais na época. Isto se expressa ainda pela adoção, como livro texto, de uma tradução renascentista do tratado De Usu Partium, de Galeno, para o latim. As medidas acima foram acompanhadas de outras, referidas no regulamento da universidade de 1559 , estipulando que duas anatomias em corpos humanos, de pacientes que tivessem morrido no hospital, deveriam ser praticadas a cada ano. Deveriam assistir às dissecações "todos os lentes e estudantes de Medicina e Cirurgia e barbeiros e todos os mais, que comodamente poderem estar na dita casa". Além das anatomias em corpos humanos, o regulamento estipulava que deveriam ser praticadas anualmente seis dissecações de "membros de animais brutos que the parecer que conformão mais com a compreiçam humana" (Estatutos..., 1963, p. 300-302; Rocha Brito, 1942).

Conquanto essas medidas possam representar a influência, em Portugal, das novas correntes do período, e Afonso de Guevara possa ter-se eventualmente dedicado à observação anatômica, há várias indicaçōes de que, na Universidade de Coimbra, a prática da anatomia era vista como um instrumento de ensino, e não um instrumento de pesquisa. Uma das diferenças essenciais entre a anatomia praticada na Idade Média, e a praticada no Renascimen- 
to, é o propósito da dissecação (French, 1979, p. 109). Trabalhos escritos por médicos que estudaram em Coimbra nos dão indicações quanto à orientação dos estudos anatômicos nessa universidade. Miranda e Henriques fazem referência à anatomia como necessária, no treinamento médico, para demonstrar, no corpo, o que havia sido aprendido em livros (Miranda, 1562, fol. 13r-13v; Henriques, 1595 , p. 208-210). Guevara baseia sua obra, em grande medida, na autoridade de Galeno. O próprio tema principal do livro, uma defesa de Galeno das críticas de Vesalius às suas descrições sobre a anatomia humana, atesta essa afiliação. Também uma passagem do Retrato del Perfecto Medico sugere que a autoridade de Galeno năo era contestada em Coimbra. Nela, Henriques argumenta que "Sospechar, o presumir que Galeno no hizo anatomia en los cuerpos humanos, es ignorãcia, y osarlo affirmar, es muy grã locura" (Henriques, 1595, p. 212).

Dissecaçōes anatômicas no Hospital de Todos os Santos em Lisboa, se é que em algum momento tiveram lugar, também parecem ter sido praticadas com o objetivo de ensinar, e não de investigar. Isto nos é sugerido pelo tratado de Antonio da Cruz, que estudou cirurgia em Lisboa. Cruz, cujo trabalho como cirurgião necessariamente implicava encontros com o corpo humano, fundamenta as concepçōes anatômicas da Recopilaçāo de Çurgia, em grande medida, no capítulo sobre anatomia da Chirurgia Magna de Guy de Chauliac (1363). No início do século XVII, Cruz aceitava como verdadeiras idéias como a de que, no corpo humano, o espirito psíquico era elaborado a partir do sangue arterial no rete mirabile, uma rede de vasos sangüíneos que se acreditava existir na base do cérebro, uma noção posta em dúvida pelos críticos renascentistas de Galeno (Cruz, 1688, p. 23-24). ${ }^{2}$ Por outro lado, junto com idéias retiradas de fontes gregas e arábico-latinas, Cruz algumas vezes faz mençāo a suas próprias observaçōes em dissecações anatômicas (Cruz, 1688, p. 25, 34 e 35). Ele também cita informações retiradas da Historia de la composicion del cuerpo humano (1556), do anatomista espanhol Juan Valverde di Hamusco (c. 1520-c. 1588).

As observações acima, sobre anatomia na Universidade de Coimbra, ilustram que, como parece ser o caso de diversos currículos médicos na Europa renascentista, o currículo de medicina em Coimbra não expressa adequadamente desenvolvimentos na medicina acadêmica da época, quando considerado em separado de outros aspectos do seu contexto. Se dissecaçōes anatômicas do

22 Sobre a crítica à noção do rete minabile e sua funçao, ver Temkin, 1973, p. 141-142. 
corpo humano foram de fato praticadas em Coimbra, elas parecem ter sido raras, apesar do previsto no regulamento da universidade e outras medidas institucionais no sentido de introduzir, lá, estudos anatômicos. Esta não é uma característica específica de Portugal. Com referência ao conhecimento anatômico na Inglaterra antes de 1640, Charles Webster nota que, nas faculdades de Oxford e Cambridge, dissecaçōes parecem ter sido praticadas apenas esporadicamente, apesar de os estatutos eduardianos prescreverem que estas deveriam ser realizadas com muito maior freqüência (Webster, 1975 , p. 121). Na Inglaterra, como em Portugal, a ausência de estudos anatômicos resultou na preeminência de Galeno no ensino médico.

A instrução clínica em Coimbra é talvez outro exemplo de uma certa tensão entre o regulamento da universidade e o modo efetivo como os estudos eram conduzidos. As fontes mais importantes sobre a instrução clínica em Portugal são os estatutos da universidade de 1559 e 1591 . Rocha Brito informa ainda que as atas do conselho universitário de 1562, 1563 e 1567 fazem referência ao ensino de medicina no Hospital Real de Coimbra (Rocha Brito, 1937, p. 22-26; Estatutos..., 1963, p. 311-314). Apesar de os estatutos prescreverem visitas regulares de professores e estudantes ao hospital, e de se ter informaçōes de que este foi remodelado tendo em vista este propósito (Teixeira de Carvalho, 1913, p. 581582 ), nenhum dos tratados estudados menciona observação de pacientes no hospital. As poucas referências à observação clínica encontradas são relativas a pacientes atendidos privadamente pelos autores médicos.

\section{IV}

$\mathrm{O}$ relacionamento entre os judeus e a medicina merece ser aqui explorado, já que um grande número entre eles praticava a profissão, e vários dos médicos letrados tinham ascendência judaica. Como no presente estudo como um todo, abordamos centralmente o domínio intelectual.

Muito já foi dito sobre a relação histórica dos judeus com o saber e a prática da medicina em vários tempos e lugares, e na Península Ibérica na Idade Média e no Renascimento em particular. Por essa razão, uma das primeiras questōes que procuramos investigar foi a de se haveria uma tradição especificamente judaica no conhecimento médico; e, se houvesse, em que ela consistiria. A resposta a estas questōes não é simples. Como nota Harry Frie- 
denwald, não chegaram até nós textos médicos dos hebreus antigos. Nossas únicas fontes são as referências médicas e higiênicas encontradas na sua literatura sagrada, histórica e legal, da qual a Bíblia é a mais importante (Friedenwald, 1967, v. 1, p. 99). Friedenwald apresenta evidências da presença de médicos judeus em sociedades cristãs e islâmicas, e sua ligação com o saber médico grego e árabe, desde a antigüidade tardia (Friedenwald, v. 2, p. 551-588; ver também Siraisi, 1990, p. 29-31). Essa ligação implica que as mais importantes idéias e fontes escritas utilizadas por médicos judeus foram retiradas da medicina grega ou islâmica. Apenas algumas práticas médicas ou médico-religiosas, particularmente no campo da higiene (banhos, a profilaxia direta da doença, o dia de descanso semanal), parecem ter-se originado na tradição judaica antiga. Nesse sentido, podemos dizer que não houve, na medicina, uma tradição hebraica separada e recebida na Europa do mesmo modo que se transmitiu uma tradição greco-islâmica.

As obras de dois importantes autores médicos judeus da Idade Média - Isaac Judaeus (c. 850-c. 940), nascido no Egito, e Moses Maimonides (1135-1204), que nasceu em Córdova e passou a maior parte da sua vida adulta no Egito - atestam a influência do saber médico grego antigo sobre os doutores judeus. O sexto aforismo do "Guia para os Médicos" (Musar Harofim), de Judaeus, afirma que "o melhor médico é aquele que se dedica a ler atentamente os escritos dos médicos antigos, especialmente os de Galeno, o príncipe dos médicos...". O décimo primeiro aforismo expressa a confiança hipocrático-galênica no poder de curar da natureza: "o médico nāo cura. Ele apenas prepara o caminho para a Natureza, que é quem verdadeiramente cura" (Judaeus, 1944, p. 183 e 184, respectivamente). Maimonides, cujo principal trabalho médico se intitula Aforismos segundo Galeno, compartilhava a estima pelos médicos gregos, Galeno em especial. Tanto Judaeus quanto Maimonides tinham fortes ligações com a medicina árabe, tendo o segundo escrito todos os seus trabalhos médicos em árabe (Friedenwald, v. 1, p. 185-192 e 201-216).

Uma consequêencia disso, quanto ao contexto português do século XVI, é que em geral não se encontram, nos textos médicos, influências distintas das da medicina grego-islâmica, que pudessem ter derivado de uma tradição médica hebraica específica. $\mathrm{O}$ papel predominante dos judeus na medicina portuguesa apresenta um outro tipo de característica distintiva: suas complexas interseçōes com os conflitos étnico-religiosos entre cristãos e judeus. Isto é bem ilustrado numa passagem da Ropicapnefina de João de Barros, na qual um dos personagens do diálogo, que argumenta a 
favor dos valores seculares, a "Vontade", pergunta ironicamente: "Qual foi o médico judeu ou mouro que não fosse a sua vista mais saudável a um cristão enfermo que a dum triste e carregado confessor?" (Barros, 1983, v. 2, p. 28).

A preponderância que judeus tiveram no exercício da medicina em Portugal parece estar ligada à relação histórica mais geral destes tanto com a medicina letrada quanto com a prática médica junto à população como um todo. A grande incidência de médicos judeus em terras portuguesas, no século XVI, se deve parcialmente à expulsão destes da Espanha, em 1492 (Jorge, 1914, p. 19-20; Pina, 1952, p. 398-399). No entanto, bem antes dessa data, os reis lusitanos os empregavam e havia muitos deles, assim como cirurgiōes judeus, no reino (Ferreira de Mira, 1947, p. 50-52; Friedenwald, 1967 , v. 2, p. 613-700, esp. p. 691-694).

O batismo em massa a que os judeus foram obrigados no final do século XV inicialmente contribuiu para ampliar a importância profissional e econômica da comunidade hebraica, na sociedade portuguesa. No período que precedeu a atividade máxima da Inquisição, intelectuais judeus, oficialmente considerados cristãosnovos, mas que em certos casos preservavam secretamente seus costumes ancestrais, ocuparam posições de destaque na corte e na universidade. Por exemplo, Antonio Luiz e Thomaz Rodrigues da Veiga, para citar somente doutores cujas obras são analisadas neste artigo, ensinaram na universidade, apesar de serem descendentes de familias judias. Se a família de Veiga tinha há tempos rompido como a fé hebraica, este não parece ter sido o caso da de Antonio Luiz, cuja ascendência era conhecida na época (Silva Dias, 1969 , v. 1, p. 229). Os médicos judeus Rodrigo de Castro e Garcia Lopes eram objeto de grande estima por parte das elites políticas portuguesas (Lemos, 1899, v. 1, p. 257-259 e 307). Dessa forma, pode-se dizer que a distinção usual entre doutores cristãos e judeus, com os últimos excluídos da universidade, não se aplica sem ressalvas a Portugal. ${ }^{2}$ Por outro lado, é preciso considerar que o único médico em cujo trabalho encontram-se influências da religião e dos costumes hebraicos, Rodrigo de Castro (Bellini, 1992, cap. 4), não era professor da universidade antes de deixar Portugal para viver em Hamburgo (c. 1588).

Um variado número de fontes dá indicaçōes sobre a crescente atmosfera de desconfiança e aversão em relação aos médicos e boticários cristãos-novos em Portugal, a partir do final do século

\footnotetext{
2. Sobre a exclusão dos judeus do ensino nas faculdades de medicina na Europa, ver Siraisi, 1990, p. 58-59.
} 
XV. Decretos reais constituem uma dessas fontes. Em 1498, D. Manuel I, em resposta à solicitação da assembléia dos nobres, plebeus e o clero, proibiu praticantes da medicina e boticários de escrever receitas médicas em línguas estrangeiras. Um decreto de 1524, de D. João III, proibiu a posse de livros em hebraico, exceto para médicos e cirurgiōes que não soubessem latim, que nesse caso poderiam utilizá-los (Friedenwald, 1967, v. 2, p. 696). Medidas como essa última, restringindo e ao mesmo tempo protegendo as atividades dos conversos, sugerem a existência de atitudes conflitantes de antagonismo e dependência em relação aos judeus, por parte da população cristâ.

A mais lamentável série de documentos indicando o antagonismo dos cristãos em relação aos médicos judeus é constituída pelos processos, confissōes e denúncias do Santo Ofício. Com base nesses registros, Friedenwald observa que "a idéia de que médicos judeus e cristãos novos deliberadamente envenenavam seus pacientes foi se tornando um mito elaborado, reforçado pelas confissōes obtidas sob tortura". Muitos foram queimados na fogueira, depois de terem confessado o assassinato de cristāos. Muitos outros deixaram Portugal para se estabelecerem em outras partes da Europa, freqüentemente retornando ao Judaísmo (Friedenwald, 1967 , v. 2, p. $697-698$ ).

A fuga dos judeus é tida por vários autores citados neste artigo como um fator que contribuiu para o declínio cultural em Portugal na segunda metade do século XVI, visto que esse processo implicou a perda de importantes intelectuais. No que diz respeito à área médica, há evidências de que doutores ilustres como Amado Lusitano, Rodrigo de Castro e Garcia Lopes deixaram Portugal devido às perseguições religiosas (Lemos, 1899, v. 1, p. 228, $259 \mathrm{e}$ 307). De forma mais geral, dado que atividades médicas de diferentes espécies eram executadas em grande parte por judeus, a perseguição e suspeita tiveram efeitos adversos sobre o domínio médico como um todo. Como ocorreu com a medicina árabe na Espanha, ${ }^{4}$ em Portugal as condições tornaram-se progressivamente menos favoráveis para a preservação e desenvolvimento da prática e saber médicos entre os judeus. Além disso, tais condições parecem ter contribuído para uma associação geral da profissão médica com as idéias de indignidade e descrédito, pela população portuguesa (Lemos, 1899, v. 1, p. 185).

24 Sobre a medicina mourisca como parte do processo geral de alienação da cultura árabe na Espanha, no século XVI, ver Ballester, 1985; e 1976, v. 1. 


\section{V}

A magnitude da intolerância étnico-religiosa contra os judeus e seus efeitos adversos sobre o campo do saber são características distintivas do contexto português do século XVI, se comparado aos demais países europeus. Tudo leva a crer que estes foram fatores decisivos que contribuíram para a trajetória do saber médico em Portugal, no final daquele século, na direção oposta à tendência geral do contexto intelectual europeu mais abrangente. A ciência médica portuguesa não acompanhou as transformaçōes no sentido da preeminência da observaçāo empírica e experimentação, que ocorreram em outros lugares da Europa.

Outro fator que parece ter contribuído para o processo acima referido, em Portugal, é a retomada do Aristotelianismo promovida pelos jesuítas, o que implicou o fortalecimento do modelo tradicional de educação em teologia, direito e ciência. Um aspecto do crescimento da Companhia de Jesus foi a sua competição com a universidade pelo papel dominante na educação superior. Isto resultou numa certa alienação da universidade, da sua posição anterior de liderança no domínio acadêmico.

Junto com as mudanças na universidade como um todo, é importante considerar condiçōes específicas da faculdade de medicina, visto que, como se sabe, o desenvolvimento da educação médica especializada estava estreitamente relacionado ao desenvolvimento da medicina como uma disciplina e uma profissâo. No que se refere ao curso de medicina em particular, há muito a universidade portuguesa vinha competindo com universidades espanholas, particularmente a de Salamanca, renomada pelo ensino médico que oferecia e cujo curso tinha duração muito menor que o de Coimbra. Por essas razões, Salamanca era muitas vezes preferida por estudantes portugueses e espanhóis (Lemos, 1899, v. 1, p. 182-184; e Jorge, 1914, p. 40-62). A maior parte dos autores médicos aqui estudados graduou-se nesta universidade. A competição com universidades espanholas também parece ter sido um fator do declínio do saber médico em Portugal.

Desenvolvimentos nos diversos ramos, abordagens e conceitos em medicina estavam de várias formas relacionados ao quadro cultural e institucional brevemente descrito acima. A medicina renascentista difere da medieval não apenas devido à redescoberta de textos gregos promovida pelos humanistas, mas também por causa do florescimento da anatomia, da fisiologia e da observaçāo

25. Para o exemplo clássico da Itália, ver Bylebyl, 1979b, esp. p. 336-338. 
clínica, assim como o progresso da botânica médica. Entre esses ramos, apenas o último sofreu transformaçōes no sentido do desenvolvimento de abordagens ligadas à observação e experimentação em Portugal, e isto nāo ocorreu em interação com outras áreas da medicina. As mudanças ocorridas no Renascimento tiveram um papel fundamental no processo de extinçāo do Galenismo. Porque elas ocorreram apenas marginalmente em terras lusitanas, Galeno continuou a dominar o conhecimento médico. Novas doutrinas, embora fossem conhecidas pelos letrados portugueses, não resultaram em inovação no pensamento médico acadêmico em Portugal.

A trajetória histórica do contexto institucional e intelectual abordado neste artigo é ilustrada por um breve exame das datas e locais de publicação dos tratados médicos estudados. Com exceção da Recopilação de Gurgia, de Antonio da Cruz (1601), os dois últimos textos médicos publicados em Portugal, dentro das balizas temporais deste estudo, são o Dialogo da perfeyçam..., de Miranda (1562) e os Commentarij in libros Claud. Galeni duos, de febrium differentijs, de Thomaz Rodrigues da Veiga (1578). A partir da data de publicação do Dialogo da perfeyçam.... textos médicos de autores portugueses foram principalmente publicados em Antuérpia, para onde parte da comunidade judaica de Portugal havia emigrado, e também em Hamburgo, Lyons e Salamanca. Como foi anteriormente sugerido, os fatores que contribuiram para esse desfecho incluem a dependência das atividades acadêmicas da patronagem e controle dos reis, cuja capacidade de promover uma ampla gama de atividades era limitada por razôes políticas e econômicas; a restauração da escolástica aristotélica; e o declínio geral da sociedade portuguesa na segunda metade do século XVI. Em conjunto com esses fatores, o êxodo dos judeus representou uma perda significativa para o domínio acadêmico como um todo, e para a medicina em particular. Pode-se talvez afirmar que, nos finais do século XVI, o contexto dos médicos portugueses localizava-se fora da Península Ibérica, nos países europeus onde muitos desses pensadores se estabeleceram. Os doutores portugueses continuaram seu trabalho em comunidades mais tolerantes em outras partes da Europa. Por tê-los acolhido, algumas dessas comunidades criaram condições para um florescimento intelectual que não viria a acontecer em Portugal. 


\section{Referências bibliográficas}

ALBUQUERQUE, Luís de. Sobre o empirismo científico em Portugal no século XVI. In: A Sociedide e a Cultura de Coimbra no Renascimento (Actas do Simpósio Internacional). Coimbra: Epartur, 1982, p. 9-25.

ANSELMO, António Joaquim. Bibliogrufia das obras impressas em Portugal no século XVI. Lisboa: Biblioteca Nacional, 1926.

ARBER, Agnes. Analogy in the history of science. In: MONTAGU, Montague Francis Ashley (ed.). Studies and essays in the history of science and learning, offernd in homage to George Sarton on the occasion of his sixtieth birthday. New York: Henry Schuman, 1947, p. 219-233.

BALLESTER, L. Garcia. Academicism versus empiricism in practical medicine in sixfeenth-century Spain with regard to morisco practitioners. In WEAR, Andrew; FRENCH, Roger; LONIE, lain (eds.). The medical renaissance of the stxteenth antury. Cambridge: Cambridge University Press, 1985, p. 246-270.

1976.

BARROS, João de. Ropicapnefma (Lisboa, 1532). Reprodução fac-similada. Leitura modernizada, notas e estudo de Israel S. Revah, 2 v., Lisboa: Instituto Nacional de investigaçào Cientifica, 1983.

BELLINI, Ligia. Representations of the human body in sixteenth-century Portugal. Colchester. Inglaterra: University os Essex, 1992 (tese de doutorado).

BRISSOT, Pierre. Apologetica disceptatio, qua docetur per quae loca sanguis mitti debeat in visceru inflammationibus, presertim in pleuritite. Paris: Simon Colinaei, 1525.

BYLEBYL, Jerome J. The medical side of Harvey's discovery: The normal and the abnormal. In: BYLEBYL, J. J. (ed.). William Harvey and his age: the professional and social context of the discovery of the circulation. Baltimore $\mathrm{e}$ Londres: Johns Hopkins University Press, 1979a, p. 28-102.

The School of Padua: humanistic medicine in the sixteenth century. In: WEBSTER, Charles (ed.). Health, medicine, and mortality in the sixteenth century. Cambridge: Cambridge University Press, 1979b, p. 335-370.

CASTRO, Rodrigo de. De universa mulierum Modicina..., Pars prima Theorica. Hamburgo: Philippe de Ohr, 1603.

CEREJEIRA, Manuel Gonçalves. O Reniscimento em Portugal. Clenardo. Coimbra: Coimbra Editora, 1974-75. $2 \mathrm{v}$.

COSTA SANTOS, S. A Escola de Cirurgia do Hospital Real de Todos os Santos, 1565-1775. Lisboa, 1925a.

boa, $1925 \mathrm{~b}$.

O início da Escola de Cirurgia do Hospital Real de Todos as Santos, 1504-1565. Lis-

CRUZ, Antonio da. Recopilaçam de cirargia. Lisboa: Miguel Deslandes, 1688.

. Recopilação de cirogia. 4.ed. Lisboa, 1630.

CUELLAR, Enrique de. Ad libros tres predictionum Hippocr. Coimbra: João Alvares e Joăo de Barreira, 1543. 
DAVID-PEYRE, Yvonne. Le thème de la maladie et le personnage du médecin dans ropica pnefma. Bulletin des Études Portugaises, XXVII, Nova Série, 1966, p. 89-118.

Estatutos da Unisersidade de Coimbra (1559). Com introdução e notas históricas e criticas de Serafim Leite, Coimbra: Universidade de Coimbra, 1963.

FERREIRA DE MIRA, M. História da medicina portuguesa. Lisboa: Empresa Nacional de Publicidade, 1947.

FOUCAULT, Michel. The order of things: an archaeology of the human sciences, Londres $e$ New York: Tavistock/Routledge, 1989.

FRENCH, R. K. De juramentis membrorum and the reception of Galenic Physiological Anatomy. Isis, 70, 1979, p. 96-109.

FRIEDENWALD, Harry. The Jews and Medicine. Essays. New York: Ktav Publishing House; Baltimore: Johns Hopkins University Press, 1967. 2 v.

Galeni liber falso adscriptus an animal sit id, quod in utero est. In: KUHN, C. G. (ed.). Claudii Galeni opera omnia. 20 v. Leipzig, 1821-33, v. 19. p. 158-181.

GARCIA LOPES. Commentarï De Varia Rei Medicae Lectione. Antuérpia: Martin Nutius, 1564.

GUEVARA, Afonso Rodrigues de. I pluribus ex ijs quibus Galenus impugnatur ab Andrea Vesalio Bruxelési in cőstructione \& usu partium corporis humani, defensio. Coimbra: João de Barreira, 1559.

HENRIQUES, Henrique Jorge. Retrato del perfecto medico. Salamanca: Renaut Impressores, 1595 .

HESSE, Mary Brenda. Madels and andogies in science. Notre Dame: University of Notre Dame Press, 1966.

JORGE, Ricardo. A Renascença médica em Portugal (Pierre Brissot e Amato Lusitano). Lusitania, 1, 1924, p. 187-192.

. Comentos à vida, obra e época de Amato Lusitano. Arquitos de História da Midicina Portuguesa, Nova Série, $5^{*}-7^{7}$ anos, 1914-1916, passim.

JUDAEUS, Isaac. Guide for Physicians (Musar Harofim) by Isaac Judaeus (880?-932?). Translated from the Hebrew, with Introduction, by Saul Jarcho. Bulletin of the History of Medicine, XV, 1944, p. 180-188.

KRISTELLER, Paul Oskar. Renaissance thought and the arts. Princeton: Princeton University Press, 1990.

LACY, Phillip De. Galen's Platonism. American Journal of Philology, 93, 1972, p. 27-39.

LEMOS, Maximiano. História da medicina em Portugal: doutrinas e instituaçōes, Lisboa: Manoel Gomes, 1899. 2 v.

LLOYD, Geoffrey Ernest Richard. Polarity and analogy: two types of argumentation in Early Greek thought. Cambridge: Cambridge University Press, 1966.

LUIZ, Antonio. De re medica opera. Lisboa: Luis Rodrigues, 1540a.

— De occoltis propriefatibus, Lisboa: Luís Rodrigues, $1540 \mathrm{~b}$.

_. Problematum libri quinq;. Lisboa: Luís Rodrigues, 1539a.

— , Panagyrica oratio elegantissima. Lisboa: Luís Rodrigues, $1539 \mathrm{~b}$. 
MACLEAN, lam. The renaissance notion of woman: a study in the fortunes of scholasticism and medical science in European infellectual life. Cambridge: Cambridge University Press, 1987.

MIRANDA, Jeronimo de. Dialogo da perfeycam e partes que sam necessarias ao bom medico. Lisboa: Joāo Alvares, 1562.

NAVARRO, Alberto. Os reportórios dos tempos, In: Navarno. Ensaios bio-bribliográficos. Lisboa, 1961, p. 9-57.

NUTTON, Vivian. Humanist surgery, In: WEAR, Andrew; FRENCH, Roger; LONIE, Jain (eds.). The medical renaissance of the sixtenth century. Cambridge: Cambridge University Press, 1985, p. 75-99.

PINA, Luis de. O Quinhentista Professor Antonto Luis na História da Psicologia e da Psiquiatria. Coimbra: Associação Portuguesa para o Progresso das Cièncias, 1957.

- Alguns aspectos históricos das relaçôes médicas luso-espanholas. Reoista de Las Ciencias, ano 18, n. 2 , p. $397-411,1952$.

- A cultura anatómica tmm Portugal no século XVI e a "Microcosmografia" de André Falcūo de Resende. Coimbra: Coimbra Editora, 1946.

As "Anatomias" de Ávila (1542) e Monserrate (1550) e a "Microcosmografia" de Falcão de Resende. Separata de Jornal do Méílico, 41, 1942.

RAMALHO. Américo da Costa. Quelques aspects de l'introduction de l'humanisme au Portugal. In: L'tumanisme portugais of L'Europe (Actes du XXIe. Colloque International d'Études Humanistes, Tours, 1978), Paris, 1984, p. 33.49.

$433-452,1972$.

A introdução do humanismo em Portugal. Separata de Humantitas, v, 23-24, p. Estudos sobre a ćpoca do Renascimento. Coimbra: Imprensa da Universidade, 1969.

RESENDE, André Falcało de. Mícrocosmographia (com outros poemas). Coimbra, 1865?, p. 3-62.

ROCHA BRITO, Alberto da. As primeiras dissecçôes humanas na Universidade de Coimbra. O primeiro teatro anatómico. Folia anafomica vniversitatis conimbrigensis, v. 17 , n. 4. 1942.

A Faculdade de Medicina no século XVI. Coimbra, 1937.

SARAIVA, António José. História da cultum em Portugal. Lisboa, 1950-62. 3 v.

SAUNDERS, J. B. de C. Mi; O'MALLEY, C. D. Andreas Vesalius Bruxellensis: the Bloodletting Letter of 1539. In: MONTAGU, Montague Francis Ashley (ed.). Studies and essays in the history of science and loaming, offered in Homage to George Sarton on the accasion of his sixfieth birthday. New York: Henry Schuman, 1947, p. 3-74.

SCHMITT, Charles. Aristotle among the physicians. In: WEAR, Andrew; FRENCH, Roger; LONIE, Iain (eds.). The medical renaissance of the sixtenth century. Cambridge: Cambridge University Press, 1985, p. 1-15.

SILVA DIAS, José Sebastião da. Os descobrimentos e a problemática cultural do século XVI. Lisboa: Presença, 1988.

A politica cultural da época de D. Joầ III. Coimbra, 1969: 2 v.

SIRAISI, Nancy G. Medieval and early renatssance medicine. Chicago e Londres, 1990. 
- The changing fortunes of a traditional text goals and strategies in sixteenthcentury Latin editions of the Canon of Avicenna. In: WEAR, Andrew; FRENCH, Roger; LONIE, Lain (eds.). The medical renaissance of the sixtenth century. Cambridge: Cambridge University Press, 1985, p. 16-41.

TAVARES DE SOUSA, A. A transferència da Universidade para Coimbra em 1537 e o ensino da medicina. In: A sociedade e a cultura de coimbra no Renascimento (Actas do Simpósio Internacional), Coimbra: Epartur, 1982, p. 165-193.

TEIXEIRA DE CARVALHO, J. M. A anatomia em Coimbra no século XVI. Revista da Untiversidade de Coimbra, II, 1913, p. 540-564.

TEMKIN, Owsei. Galenism: rise and decline of a medical phitosopiny. Ithaca e Londres: Cornell University Press, 1973.

VASCONCELLOS, Joaquim de. Albrecht Dïrer e a sua infiuência na Pentisula. Coimbra: Imprensa da Universidade, 1929.

VEIGA, Thomas Rodrigues da. Opera onmia in Galeni libros edifa. Lyons: Petrum Landry, 1587.

- Commentarit in libros Hippocratis de victus ratione. Lyons, 1586.

- Commentarij in libros Claud, Galeni duos, de febrium differentijs. Coimbra: Joło de Barreira, 1578

- Tom s primvs Commentariorvm in Clavdit Galeni opera,... Complectens interpretationem Artis medicae, \& librorum sex De locis affectis. Antuérpia: Christophorus Plantini, 1564.

VICKERS, Brian. Analogy versus identity: the rejection of occult symbolism, 1580-1680*, In: VICKERS (ed.). Occult and scientific mentalities in the Renaissance. Cambridge: Cambridge University Press, 1984, p. 95-163.

WATERS, David W. Science and the techniques of navigation in the Renaissance. In: SINGLETON, Charles (ed.). Art, science and history in the Renaissance. Baltimore: Johns Hopkins University Press, 1967, p. 189-237.

WEAR, Andrew; FRENCH, Roger; LONIE, lain (ed5.). The medical nenaissance of the sixteenth century. Cambridge: Cambridge University Press, 1985

WEBSTER, Charles. The great instauration: science, medicine and Reform 1626-1660. Londres: Duckworth, 1975.

WILSON, Luke. William Harvey's prelectiones: the performance of the body in the renaissance theater of anatomy. Rupresentations, 17, 1987, p. 62-95. 